\title{
Inhibition of Organic Anion Transport in Endothelial Cells by Hydrogen Peroxide
}

\author{
Daniel B. Hinshaw, ${ }^{* 1}$ Jeanne M. Burger,* Ralph E. Delius,* \\ Paul A. Hyslop, $\nmid$ and Geneva M. Omann*, + \\ Departments of *Surgery and $\ddagger$ Biological Chemistry, VAMC and the University of Michigan, Ann Arbor, Michigan; \\ and $\dagger$ CNS Division, Lilly Research Laboratories, Indianapolis, Indiana
}

\begin{abstract}
A'TP loss is a prominent feature of cellular injury induced by oxidants or ischemia. How reduction of cellular ATP levels contributes to lethal injury is still poorly understood. In this study we examined the ability of $\mathrm{H}_{2} \mathrm{O}_{2}$ to inhibit in a dose-dependent manner the extrusion of fluorescent organic anions from bovine pulmonary artery endothelial cells. Extrusion of fluorescent organic anions was inhibited by probenecid, suggesting an organic anion transporter was involved. In experiments in which ATP levels in endothelial cells were varied by treatment with different degrees of metabolic inhibition, it was determined that organic anion transport was ATP-dependent. $\mathrm{H}_{2} \mathrm{O}_{2}$-induced inhibition of organic anion transport correlated well with the oxidant's effect on cellular ATP levels. Thus $\mathrm{H}_{2} \mathrm{O}_{2}$-mediated inhibition of organic anion transport appears to be via depletion of ATP, a required substrate for the transport reaction. Inhibition of organic anion transport directly by probenecid or indirectly by metabolic inhibition with reduction of cellular ATP levels was correlated with similar reductions of short term viability. This supports the hypothesis that inhibition of organic anion transport after oxidant exposure or during ischemia results from depletion of ATP and may significantly contribute to cytotoxicity. 1992 Academic Press, Inc.
\end{abstract}

Oxidants generated from the reduction of molecular $\mathrm{O}_{2}$ have been implicated as important mediators of toxic cellular injury in inflammation and after reperfusion of ischemic tissues $(1,2)$. The toxicity of one of the most ubiquitous of these oxidants, hydrogen peroxide $\left(\mathrm{H}_{2} \mathrm{O}_{2}\right)$, has been extensively studied. Exposure to $\mathrm{H}_{2} \mathrm{O}_{2}$ initiates a sequence of biochemical events which includes rapid ac-

\footnotetext{
${ }^{1}$ To whom correspondence should he addressed at Surgery Service (112), VA Medical Center, 2215 Fuller Road, Ann Arbor, MI 48105. Fax: (313) 769-7056.
}

tivation of the nuclear enzyme poly(ADP-ribose) polymerase in association with DNA strand breakage (3-6); disruption of intracellular $\mathrm{Ca}^{2+}$ homeostasis $(7,8)$; activation of the glutathione redox cycle (9); lipid peroxidation (10); inhibition of the glycolytic enzyme, glyceraldehyde 3-phosphate dehydrogenase, and inhibition of mitochondrial ADP phosphorylation, with a resultant inhibition of glucose-dependent ATP synthesis (11-13); and cytoskeletal alterations including oxidation of sulfhydryl groups in actin, induction of actin polymerization, an ATP-dependent disruption of visible microfilament organization, and alteration of cellular morphology including membrane blebbing (14-20).

The precise role which loss of ATP plays in $\mathrm{H}_{2} \mathrm{O}_{2}$-mediated cytotoxicity is unclear (21). Recently we have demonstrated that significant improvement of short term viability of endothelial cells following $\mathrm{H}_{2} \mathrm{O}_{2}$ exposure can be achieved by increasing ATP levels in association with glutamine administration $(22,23)$. These short term benefits are not borne out over $24 \mathrm{~h}$, however, suggesting that other mechanisms may come into play in regard to longer term cell survival after $\mathrm{H}_{2} \mathrm{O}_{2}$ injury (23). Some of the toxic effects of $\mathrm{H}_{2} \mathrm{O}_{2}$ on cells, such as disruption of visible microfilament organization and loss of intracellular $\mathrm{Ca}^{2+}$ homeostasis, appear to be at least in part a result of the effect of $\mathrm{H}_{2} \mathrm{O}_{2}$ on ATP levels within the injured cells (7, $8,15,16)$. In endothelial cells, intracellular $\mathrm{Ca}^{2+}$ homeostasis is remarkably stable in response to large reductions of cellular ATP induced by metabolic inhibitors or $\mathrm{H}_{2} \mathrm{O}_{2}$ (8). Although $\mathrm{H}_{2} \mathrm{O}_{2}$ concentrations of approximately 500 $\mu \mathrm{M}$ can significantly reduce ATP levels and produce dramatic ATP dependent disruption of visible microfilament organization, only concentrations of $\mathrm{H}_{2} \mathrm{O}_{2} \geqslant 5 \mathrm{mM}$ alter $\mathrm{Ca}^{2+}$ homeostasis and induce $\mathrm{Ca}^{2+}$-dependent microtubule depolymerization in endothelial cells (8). Similarly, only when ATP loss from metabolic inhibition is combined with exposure to $\mathrm{Ca}^{2+}$ ionophore is there a sustained elevation of intracellular $\mathrm{Ca}^{2+}$ in these cells (8).

0003-9861/92 $\$ 5.00$ Copyright (c) 1992 by Academic Press, Inc All rights of reproduction in any form reserved 
In earlier work (7) we noted that cellular exposure to low millimolar concentrations of $\mathrm{H}_{2} \mathrm{O}_{2}$ was associated with an inhibition of extrusion of the fluorescent organic anion dye, Quin 2, from the injured cells. Jacobs et al. (24) have noted a similar phenomenon in which the extrusion of fura-2 from rabbit proximal tubules was inhibited after exposure to metabolic inhibition. Recently, it has been demonstrated that macrophages contain a probenecidinhibitable organic anion transporter (25) which also appears to be present in granulocytes (26). This observation has made it possible to use probenecid as a means of preventing rapid extrusion of fluorescent organic anion dyes during physiologic studies of cellular function, although it has been noted that exposure to probenecid itself for several hours can be toxic to cells $(25,27)$.

In this study we present data demonstrating that bovine pulmonary artery endothelial cells possess a probenecidinhibitable organic anion transporter and that organic anion transport in endothelial cells can also be inhibited by $\mathrm{H}_{2} \mathrm{O}_{2}$ exposure. Furthermore, we demonstrate that organic anion transport is ATP-dependent and that the inhibition of organic anion transport by $\mathrm{H}_{2} \mathrm{O}_{2}$ is correlated with $\mathrm{H}_{2} \mathrm{O}_{2}$ effects on endothelial ATP levels. Finally, we hypothesize that inhibition of organic anion transport in endothelial cells by $\mathrm{H}_{2} \mathrm{O}_{2}$ may be an important mechanism of ATP-dependent rapid cell death.

\section{MATERIALS AND METHODS}

Cells and culture. Bovine pulmonary artery endothelial cells used in these experiments were from the National Institute of Aging, Aging Cell Culture Repository (No. AG2791A; Camden, NJ). They were cultured at $37^{\circ} \mathrm{C}$ under $5 \% \mathrm{CO}_{2} / 95 \%$ air in medium RPMI 1640 supplemented with $2 \mathrm{mM}$ glutamine (GIBCO, Grand Island, NY), $10 \%$ fetal bovine serum (Whittaker, M.A. Bioproducts, Walkersville, MD), $100 \mu / \mathrm{ml}$ penicillin, and $100 \mu \mathrm{g} / \mathrm{ml}$ streptomycin (GIBCO), and $10 \mathrm{mM}$ Hepes for additional buffering capacity. Cells were grown in $75-$ or $150-\mathrm{cm}^{2}$ flasks (Corning, Corning, NY). Cells from passages 4 to 10 were used for these experiments. Cells were suspended after a $10-$ to $15-\mathrm{min}$ exposure to trypsin $(0.05 \%)$-EDTA $(0.02 \%)$ (Sigma, St. Louis, MO). Experiments were carried out using modified Geys buffer (MGB) ${ }^{2}$ containing $147 \mathrm{mM}$ $\mathrm{NaCl}, 5 \mathrm{mM} \mathrm{KCl}, 1.9 \mathrm{mM} \mathrm{KH} \mathrm{PO}_{4}, 1.1 \mathrm{mM} \mathrm{Na}_{2} \mathrm{HPO}_{4}, 0.3 \mathrm{mM} \mathrm{MgSO}$, $1 \mathrm{mM} \mathrm{MgCl}, 10 \mathrm{mM}$ Hepes, $1.5 \mathrm{mM} \mathrm{CaCl}$, and $5.5 \mathrm{mM}$ glucose at $\mathrm{pH}$ 7.4. Under some experimental conditions, glucose was deleted from the buffer or glutamine $(2 \mathrm{mM})$ was added.

Cellular loading with organic anion fuorophores and assay of organic anion transport. Endothelial cells $\left(1 \times 10^{7}\right.$ cells $\left./ \mathrm{ml}\right)$ in MGB were warmed to $37^{\circ} \mathrm{C}$ for $5 \mathrm{~min}$. The acetoxymethyl esters of Quin 2, Quin 2-AM, or of $2^{\prime}, 7^{\prime}$-bis-(2-carboxyethyl)-5(and -6) carboxyfluorescein, BCECF-AM (Molecular Probes, Inc., Junction City, OR), were prepared as 5 and $1 \mathrm{mM}$ stock solutions in DMSO, respectively, and were added to the cells with stirring over $1 \mathrm{~min}$ to give final concentrations of 50 $\mu \mathrm{M}$ Quin 2-AM and $5 \mu \mathrm{M}$ BCECF-AM. The cell suspension in a 50-ml centrifuge tube was then placed on a nutator (rotational stirring device) for $25 \mathrm{~min}$ at $37^{\circ} \mathrm{C}$. At the end of the 25 -min labeling period, the cells were washed with an excess of MGB and centrifuged at 1.500 RPM for

\footnotetext{
${ }^{2}$ Abbreviations used: MGB, modified Geys buffer; AM, acetoxymethyl; BCECF, 2',7'-bis-(2-carboxyethyl)-5(and -6) carboxyfluorescein; DMSO, dimethyl sulfoxide; TX-100, Triton X-100.
}

$5 \mathrm{~min}$, and the pellet was resuspended in MGB at a concentration of 2 $\times 10^{6}$ cells $/ \mathrm{ml}$ and placed on ice until ready for use.

Prior to the extrusion assay, labeled cells were warmed for $5 \mathrm{~min}$ at $37^{\circ} \mathrm{C}$. At time zero, a bolus of $\mathrm{H}_{2} \mathrm{O}_{2}$, oligomycin, or $\mathrm{KCN}$ was added. For probenecid samples, cells were centrifuged after 5 min of warming to $37^{\circ} \mathrm{C}$ and then resuspended in warm MGB containing the appropriate concentration of probenecid. If the sample was to be depleted of glucose, the cells were washed in cold MGB without added glucose twice prior to the 5-min period of warming. In some experiments $11 \mathrm{~mm}$ 2-deoxyglucose was also present in the glucose-free MGB during the extrusion assay. In samples depleted of glucose for $4 \mathrm{~h}$ prior to assay, unlabeled cells were incubated in glucose-free MGB for $3.5 \mathrm{~h}$ at $37^{\circ} \mathrm{C}$ and Quin 2 was then added to the sample for the last $25 \mathrm{~min}$ of the 4-h incubation being loaded as described above using glucose-free MGB for the wash steps and for the incubation media during the assay. Glucose depletion for $4 \mathrm{~h}$ did not alter the efficiency of Quin 2 loading by the cells (data not shown).

At each time point during the 2 - $h$ time course of the extrusion assay, a $0.5-\mathrm{ml}$ sample of the cell suspension was removed and centrifuged quickly $(30 \mathrm{~s})$ in a microcentrifuge. The supernatant was removed and added to a cuvette containing $1.5 \mathrm{ml}$ of $\mathrm{MGB}$, and the fluorescence was read on an SLM $8000 \mathrm{C}$ spectrofluorometer $(340 \mathrm{~nm}$, excitation wavelength, and $520 \mathrm{~nm}$, emission wavelength, for Quin 2; $490 \mathrm{~nm}$, excitation wavclength, and $520 \mathrm{~nm}$, cmission wavelength, for BCECF). Intracellular fluorescence due to Quin 2 or BCECF was quantitated in the same manner after resuspension of the pellet in $2 \mathrm{ml}$ of MGB to which a final concentration of $0.075 \%$ Triton X-100 (TX-100) was added, thus making it possible to measure the fluorescence of the intracellular fluorophore under essentially the same $\mathrm{pH}$ and ionic conditions as for the fluorophore present in the supernatant. No further increase in fluorescence of either fluorophore was detected upon addition of more TX-100, confirming that complete lysis of the cells had occurred. For each time point, the total fluorescence was determined as the sum of the fluorescence of the supernatant plus the fluorescence of the extracted pellet. The percentage of cell-associated organic anion fluorophore was determined from the relationship (fluorescence of the extracted cell pellet/total fluorescence of the sample) $\times 100 \%$. Total fluorescence for individual samples throughout the 2-h time course remained constant (data not shown).

ATP measurements. Measurement of ATP in the endothelial cells at each time point during the assay of organic anion transport was performed as previously reported using the luciferin-luciferase assay $(17,28)$.

Viability measurements. Cellular viability was determined by the ability of the endothelial cells to exclude trypan blue. Fifty microliters of cell suspension was incubated briefly with $12 \mu \mathrm{l} 0.1 \%$ trypan blue in $0.9 \% \mathrm{NaCl}$ (final concentration approximately $0.02 \%$ ). The number of cells excluding trypan blue out of 100 cells counted on a hemocytometer was expressed as the percentage of viable cells.

Statistics. Data are presented as the mean \pm SD. Statistical comparisons were made using repeated measures analysis of variance with $P<0.05$ being considered significant. Correlation of cell-associated organic anion fluorophore with ATP levels was determined by least squares linear regression.

\section{RESULTS}

\section{Probenecid-Sensitive Transport of Quin 2 by Endothelial Cells}

Endothelial cells loaded with Quin 2 were incubated at $37^{\circ} \mathrm{C}$ in the presence of $0-5 \mathrm{mM}$ probenecid over a $2-\mathrm{h}$ time course. The percentage of cell-associated Quin 2 was determined immediately after addition of probenecid and at 30,60 , and $120 \mathrm{~min}$ of exposure to the drug. Progressively greater degrees of inhibition of Quin 2 extrusion from endothelial cells were seen with increasing concen- 


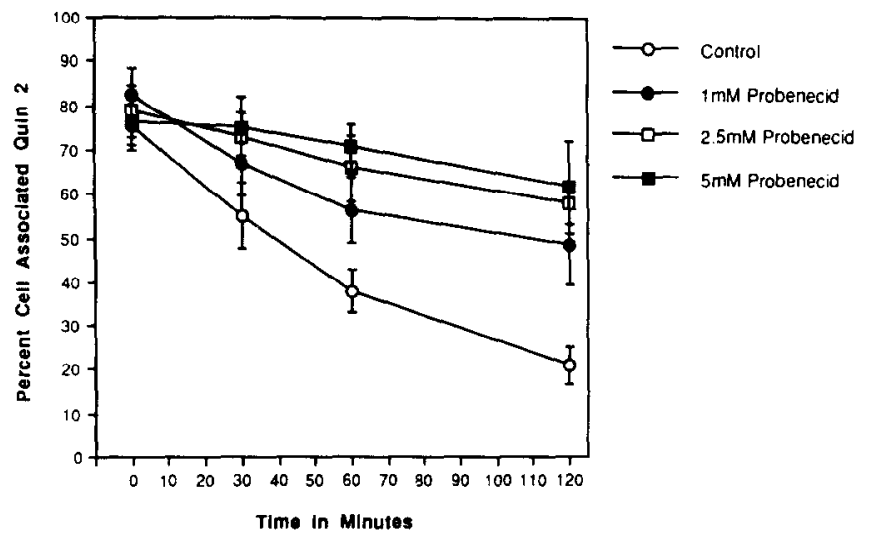

FIG. 1. The effect of probenecid on the extrusion of Quin 2 from endothelial cells. Cells were loaded with Quin 2 as described under Materials and Methods. At time zero, cells were resuspended in buffer containing probenecid and cell associated Quin 2 was measured at $37^{\circ} \mathrm{C}$ over a 2-h time course (see Materials and Methods for details). Each data point represents the mean $\pm \mathrm{SD}$ of $N=4-12$ separate determinations.

trations of probenecid (Fig. 1). Thus, extrusion of Quin 2 from endothelial cells occurred via a probenecid-inhibitable mechanism, presumably via an organic anion transporter as has been described for other cells $(25,26)$.

\section{$\mathrm{H}_{2} \mathrm{O}_{2}$-Induced Inhibition of Quin 2 Transport by Endothelial Cells}

$\mathrm{H}_{2} \mathrm{O}_{2}$ exposure induced a dose-dependent inhibition of Quin 2 transport out of endothelial cells over a 2-h time course (Fig. 2). Whereas approximately $50 \%$ of cell-associated Quin 2 was lost from control cells after $2 \mathrm{~h}$, progressively greater amounts of the fluorophore were retained within the cells after exposure to increasing concentrations of $\mathrm{H}_{2} \mathrm{O}_{2}$ (Fig. 2). Concentrations of $\mathrm{H}_{2} \mathrm{O}_{2}$ $\geqslant 1 \mathrm{mM}$ were associated with only a small amount of Quin 2 extrusion, comparable to that seen with probenecid treatment (Fig. 1). Significant $(P=0.0152)$ inhibition of Quin 2 extrusion over the 2-h time course was seen with concentrations of $\mathrm{H}_{2} \mathrm{O}_{2}$ as low as $500 \mu \mathrm{M}$.

\section{ATP and the Activity of the Probenecid-Sensitive Anion Transporter}

Since the greatest inhibition of Quin 2 transport from endothelial cells after $\mathrm{H}_{2} \mathrm{O}_{2}$ exposure occurred with concentrations of the oxidant previously associated with substantial reductions of cellular ATP levels $(8,22,23)$, we examined the effect on organic anion transport of different conditions which could decrease cellular ATP levels independent of oxidant exposure (see Materials and Methods for details). Figure 3 demonstrates the effect of different types of metabolic inhibition on the transport of Quin 2 out of endothelial cells over a 2-h time course. It becomes apparent that when the data in Fig. 3 are com-

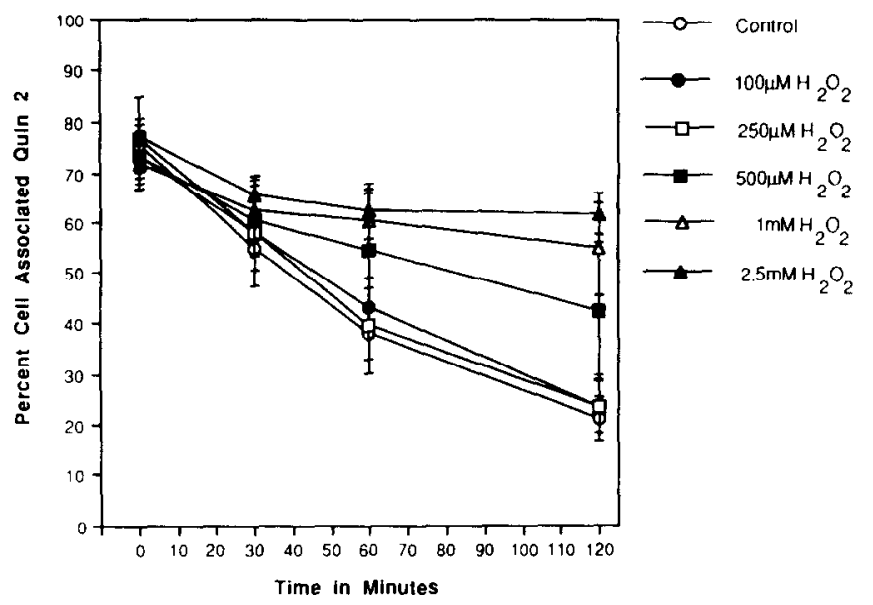

FIG. 2. The effect of $\mathrm{H}_{2} \mathrm{O}_{2}$ exposure on the extrusion of Quin 2 from endothelial cells. Cells were loaded with Quin 2 and at time zero a bolus of $\mathrm{H}_{2} \mathrm{O}_{2}$ was added and cell associated Quin 2 was measured over a 2-h time course. Each data point represents the mean $\pm \mathrm{SD}$ of $N=4-12$ separate determinations.

pared with ATP levels measured under the same conditions over the 2-h time course (Fig. 4), progressively greater degrees of metabolic inhibition and reduction of ATP levels are associated with greater inhibition of transport of the fluorophore out of the cells.

Recently, we have demonstrated the ability to significantly improve ATP levels in endothelial cells injured by $\mathrm{H}_{2} \mathrm{O}_{2}$ by supplementation of the cells with the amino acid glutamine $(22,23)$. To demonstrate more directly that

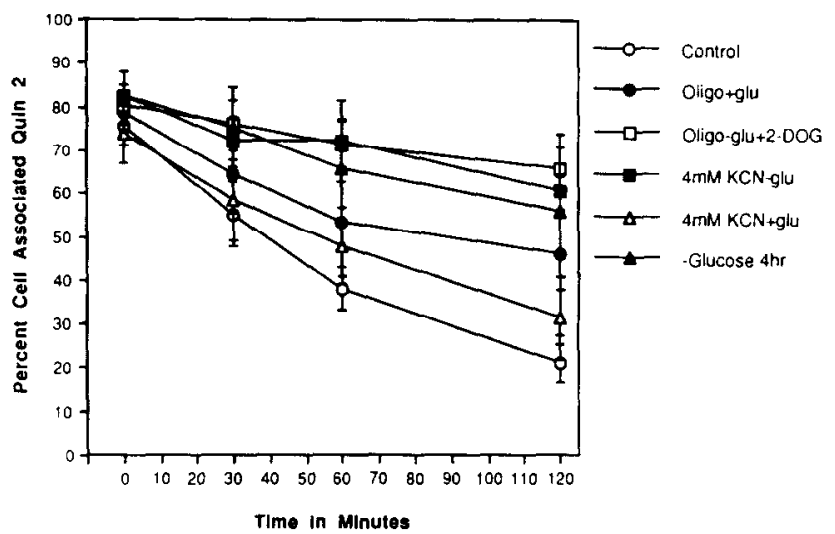

FIG. 3. The effect of metabolic inhibition on the extrusion of Quin 2 from endothelial cells. Cells were loaded with Quin 2 and then exposed to the following conditions: (1) resuspension in MGB plus glucose to which $650 \mathrm{nM}$ oligomycin (oligo) or $4 \mathrm{mM} \mathrm{KCN}$ was added at time zero; (2) resuspension in MGB minus glucose containing $11 \mathrm{mM}$ 2-deoxyglucose (2-DOG) to which $650 \mathrm{nM}$ oligomycin was added at time zero; (3) resuspension in MGB minus glucose to which $4 \mathrm{mM} \mathrm{KCN}$ was added at time zero; (4) the minus glucose 4-h sample was depleted of glucose for $3.5 \mathrm{~h}$ prior to loading with Quin 2 under glucose-depleted conditions. The cells remained in glucose-free buffer throughout the assay. Each data point represents the mean $\pm \mathrm{SD}$ of $N=3-12$ separate determinations. 


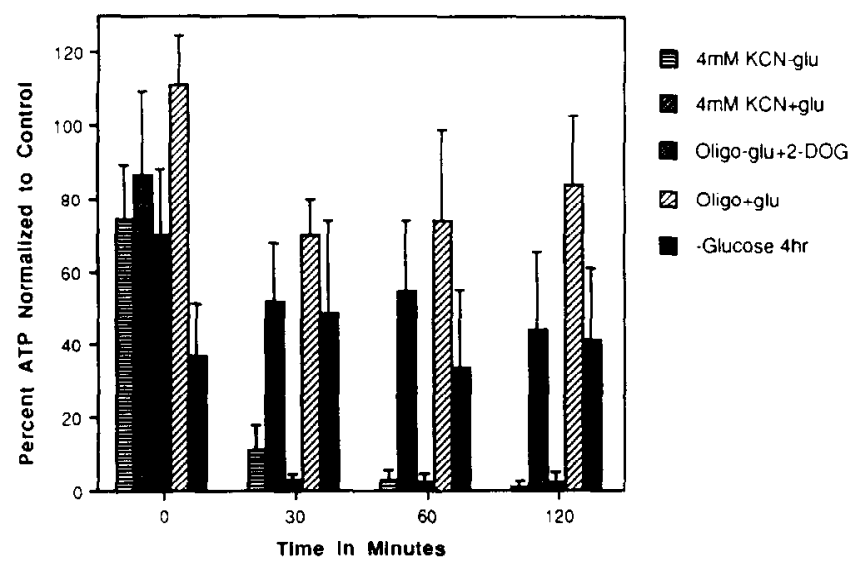

FIG. 4. The effect of metabolic inhibition on ATP levels in endothelial cells. Control ATP levels over the 2-h time course ranged from $8.93 \pm$ 4.39 to $6.71 \pm 3.05 \mathrm{nmol} / 2 \times 10^{6}$ cells, $N=11$ and 13 , respectively. Conditions were the same as for Fig. 3. Each bar represents the mean $\pm \mathrm{SD}$ of $N=4-8$ separate determinations.

$\mathrm{H}_{2} \mathrm{O}_{2}$ effects on organic anion transport in endothelial cells were in proportion to $\mathrm{H}_{2} \mathrm{O}_{2}$-induced loss of cellular ATP we examined the effect of glutamine supplementation during $\mathrm{H}_{2} \mathrm{O}_{2}$ exposure on organic anion transport in the cells (Fig. 5A). Exposure to $5 \mathrm{mM} \mathrm{H}_{2} \mathrm{O}_{2}$ in the presence of $2 \mathrm{mM}$ glutamine was associated with a significant $(P$ $=0.0002$ ) increase in the rate of organic anion transport compared to that of $\mathrm{H}_{2} \mathrm{O}_{2}$-injured cells without glutamine present. This correlated well with a glutamine-associated increase in ATP levels in the injured cells (Fig. 5B) which was also significant $(P=0.0225)$. Treatment of $\mathrm{H}_{2} \mathrm{O}_{2}$ injured cells with glutamine did not completely restore ATP or organic anion transport to the levels seen in control cells. Glutamine did not significantly alter ATP levels or organic anion transport in control cells.

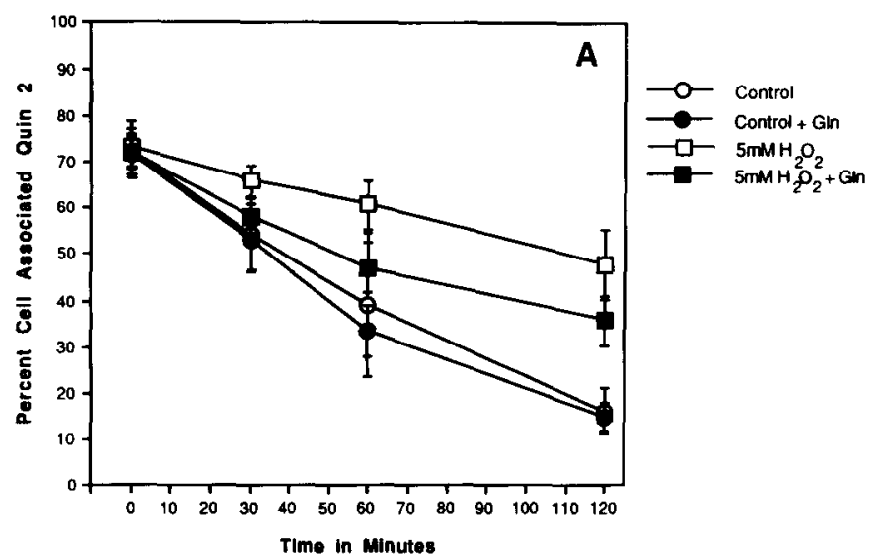

\section{The Organic Anion Transporter is not Specific} for Quin 2

To determine whether $\mathrm{H}_{2} \mathrm{O}_{2}$ could also inhibit probenecid-sensitive transport of other organic anions from endothelial cells, extrusion of the fluorophore, BCECF, after endothelial exposure to $\mathrm{H}_{2} \mathrm{O}_{2}$ or probenecid was monitored over a 2-h time course (Fig. 6). BCECF was extruded from control endothelial cells to a similar extent as Quin 2. Both probenecid $(5 \mathrm{mM})$ and $\mathrm{H}_{2} \mathrm{O}_{2}(2.5 \mathrm{mM})$ inhibited extrusion of BCECF from the cells (Fig. 6) although not as effectively as they inhibited Quin 2 extrusion. When ATP levels in the cells had been reduced substantially, at time points $\geqslant 30 \mathrm{~min}$, the rate of loss of BCECF from cells exposed to $\mathrm{H}_{2} \mathrm{O}_{2}$ began to slow down (Fig. 7).

\section{Correlation of Cellular ATP Levels and Endothelial Organic Anion Transport}

When ATP levels in endothelial cells measured at 120 min under the different experimental conditions present in Figs. 2 and 3 were correlated with the percentage of cell associated Quin 2, there was a highly significant ( $P$ $=0.0003)$ correlation $(r=-0.8828)$ between reduction of cellular ATP levels and retention of the fluorophore by the cells (Fig. 8). These data were consistent with the hypothesis that reduction of ATP levels in $\mathrm{H}_{2} \mathrm{O}_{2}$-injured endothelial cells accounted for the inhibition of organic anion transport.

\section{Inhibition of Organic Anion Transport and Endothelial Cell Injury}

Probenecid has been reported to exert toxic effects on cells (25). It has also been unclear what precise role ATP reductions may play in oxidant-mediated cell killing (21, 23). We next compared the effect two different means of

FIG. 5. The effect of glutamine supplementation on the extrusion of Quin 2 and ATP levels in endothelial cells exposed to $\mathrm{H}_{2} \mathrm{O}_{2}$. (A) Time course of Quin 2 extrusion from endothelial cells. Each data point represents the mean $\pm \mathrm{SD}$ of $N=7$ or 8 separate determinations. Glutamine (Gln) at a final concentration of $2 \mathrm{mM}$ was added at the time of $\mathrm{H}_{2} \mathrm{O}_{2}$ addition. (B) Time course of ATP levels in endothelial cells. Each bar represents the mean \pm SD of $N-6$ or 7 separate determinations. 


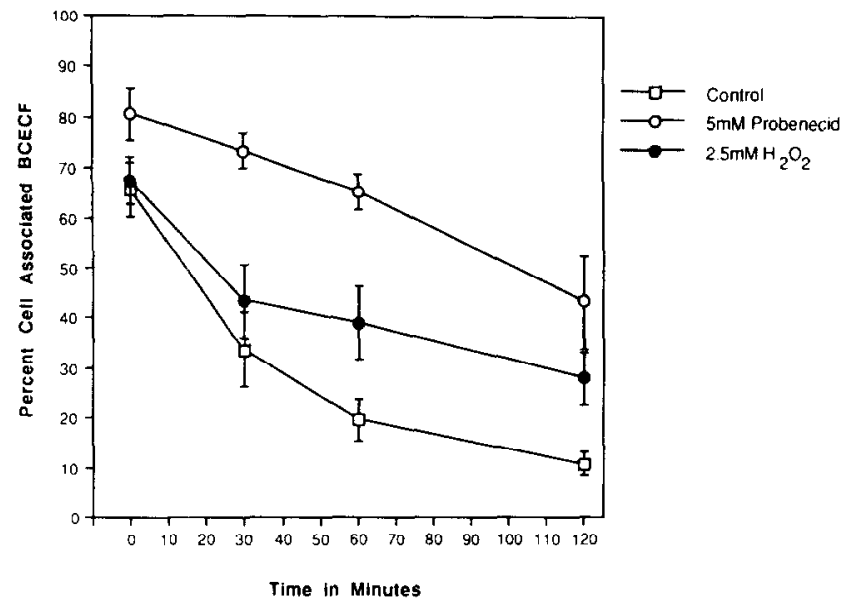

FIG. 6. The effect of probenecid and $\mathrm{H}_{2} \mathrm{O}_{2}$ on the extrusion of BCECF from endothelial cells. Cells were loaded with BCECF and at time zero probenecid (final concentration $5 \mathrm{mM}$ ) or $\mathrm{H}_{2} \mathrm{O}_{2}$ (final concentration 2.5 $\mathrm{mM}$ ) were added and cell-associated BCECF was measured over a 2 -h time course. Each data point represents the mean $\pm \mathrm{SD}$ of $N=5$ separate determinations.

producing a comparable degree of anion transport inhibition had on short term viability of the endothelial cells. Exposure of endothelial cells to $5 \mathrm{mM}$ probenecid or 650 nM oligomycin plus $11 \mathrm{mM} 2$-deoxyglucose produced very similar patterns of inhibition of the transport of Quin 2 out of the cells (see Figs. 1 and 3 ). In contrast to this, ATP levels were quite different over the same time course in response to the two treatments. Metabolic inhibition with oligomycin and 2-deoxyglucose produced a dramatic reduction of ATP levels to $<5 \%$ of control levels after 30 $\min$ (Fig. 4), whereas probenecid did not produce any significant early effect on ATP levels (Fig. 7) or at later time

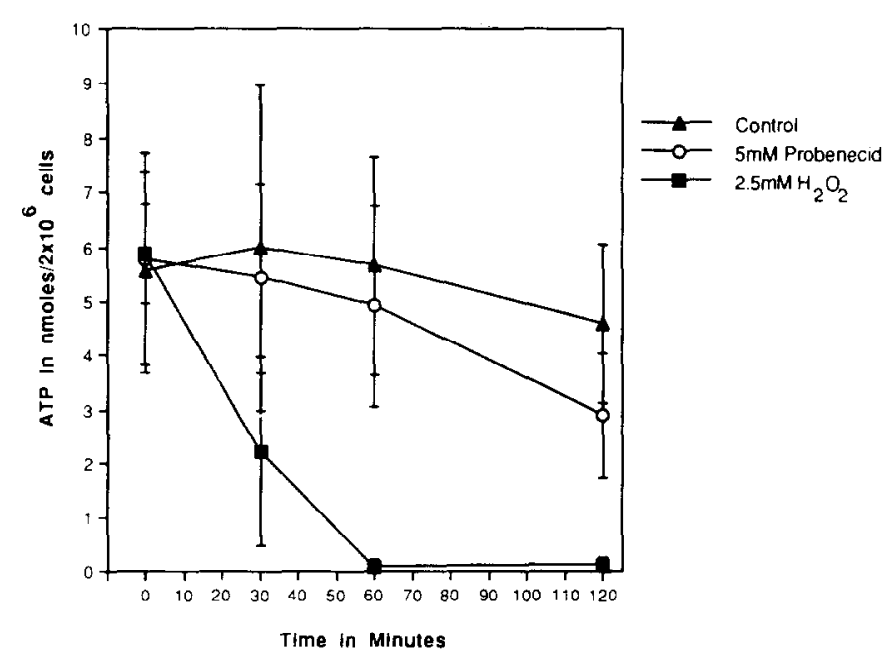

FIG. 7. The effect of probenecid and $\mathrm{H}_{2} \mathrm{O}_{2}$ on ATP levels in endothelial cells from the experiment in Fig. 6. Conditions were the same as for Fig. 6. Each data point represents the mean $\pm \mathrm{SD}$ of $N=4$ or 5 separate determinations.

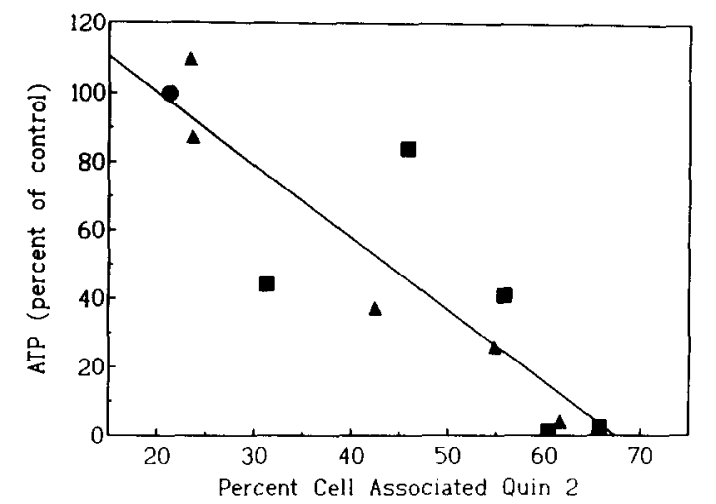

FIG. 8. Correlation of cell associated Quin 2 with cellular ATP levels at the end of the 2-h assay. Data has been taken from the $120 \mathrm{~min}$ time point of Figs. 2-4. Circle, control; triangles, $\mathrm{H}_{2} \mathrm{O}_{2}$ exposure; squares, metabolic inhibition. ATP data presented for $\mathrm{H}_{2} \mathrm{O}_{2}$-treated samples (not shown in Figs. 2-4) represent the mean of $N=4-8$ separate determinations.

points (control $=3.18 \pm 0.68 \mathrm{nmol} / 2 \times 10^{6}$ cells vs probenecid $=2.81 \pm 1.14 \mathrm{nmol} / 2 \times 10^{6}$ cells at $6 \mathrm{~h} ; N=3$ ). Short term viability measured over a 6 -h time course showed a progressive time-dependent reduction of viability $(P<0.01)$ under the two conditions in which anion transport was inhibited (Fig. 9). The difference between the effect of probenecid and the metabolic inhibitors on endothelial viability was not significantly different over the time course. These observations support the concept that inhibition of organic anion transport associated with reduction of ATP levels in endothelial cells after $\mathrm{H}_{2} \mathrm{O}_{2}$ exposure may play an important role in the mechanism of $\mathrm{H}_{2} \mathrm{O}_{2}$-induced cytotoxicity.

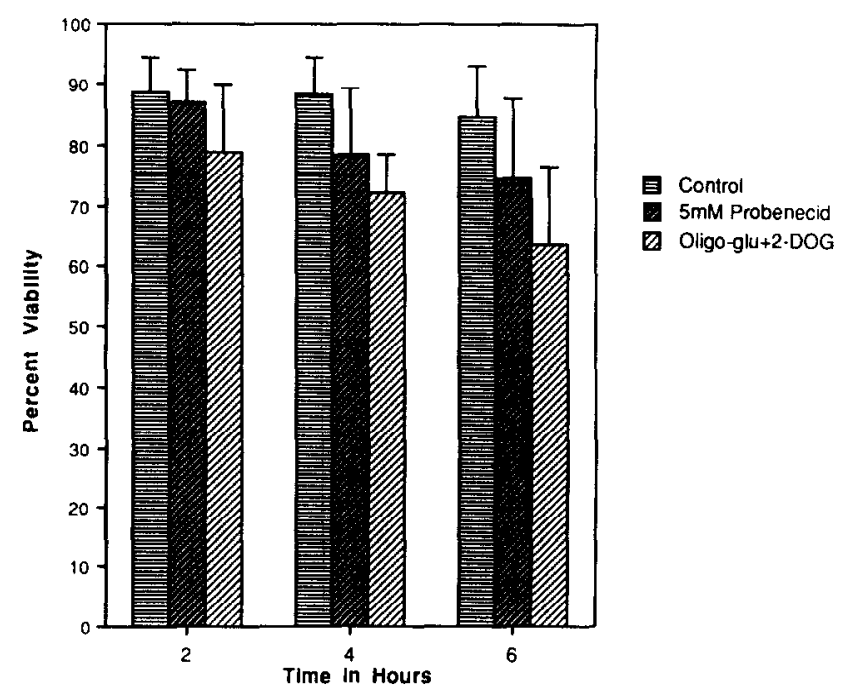

FIG. 9. The effect of conditions which inhibit organic anion transport on endothelial cell viability (trypan blue exclusion). Each bar represents the mean $\pm \mathrm{SD}$ of $N=6-10$ separate determinations. 


\section{DISCUSSION}

Using two different organic anion fluorophores, we have demonstrated that a probenecid-inhibitable organic anion transporter is present within bovine pulmonary artery endothelial cells. $\mathrm{H}_{2} \mathrm{O}_{2}$ exposure produced a dose-dependent inhibition of organic anion transport. Progressively greater degrees of metabolic inhibition (with associated ATP loss) were also correlated with inhibition of fluorophore extrusion from the cells. In cells treated with $\mathrm{H}_{2} \mathrm{O}_{2}$ or metabolic inhibition, retention of cell-associated fluorophore at the end of the assay period was highly correlated with reduction of cellular ATP levels. Experiments with glutamine supplementation during $\mathrm{H}_{2} \mathrm{O}_{2}$ exposure also demonstrated in a more direct fashion that $\mathrm{H}_{2} \mathrm{O}_{2}$ inhibits organic anion transport in endothelial cells via its effect on cellular ATP levels.

It is interesting that with either fluorophore the degree to which probenecid treatment inhibited dye extrusion was similar to the effect of $\mathrm{H}_{2} \mathrm{O}_{2}$. Thus, when probenecid produced nearly complete inhibition of Quin 2 extrusion so did $\mathrm{H}_{2} \mathrm{O}_{2}$, whereas similar dosages of probenecid and $\mathrm{H}_{2} \mathrm{O}_{2}$ only partially inhibited BCECF extrusion, suggesting that BCECF may also be extruded from endothelial cells by another mechanism. $\mathrm{H}_{2} \mathrm{O}_{2}$-mediated inhibition of BCECF extrusion also became more prominent at time points when ATP levels in the injured cells were quite low (Fig. 7), lending further support to the concept that the $\mathrm{H}_{2} \mathrm{O}_{2}$-mediated inhibition of organic anion transport was a result of reduction of cellular ATP levels.

Varani et al. (21) have recently been able to dissociate ATP loss from lethal oxidant injury of endothelial cells. We have been able to demonstrate a significant ATPrelated improvement in short term $(6 \mathrm{~h})$ endothelial cell viability after oxidant exposure with glutamine supplementation (23). Glutamine supplementation with the associated increase in cellular ATP levels did not improve later survival data at $24 \mathrm{~h}$, however (23). When compared with previously published data, these experiments have demonstrated that organic anion transport is more sensitive to ATP loss from metabolic inhibition or $\mathrm{H}_{2} \mathrm{O}_{2}$ exposure than is intracellular $\mathrm{Ca}^{2+}$ homeostasis (8). Although inhibition of organic anion transport was demonstrable with $\mathrm{H}_{2} \mathrm{O}_{2}$ concentrations $\geqslant 500 \mu \mathrm{M}$, a 10 fold increase in the concentration of the oxidant was needed to cause an elevation of intracellular $\mathrm{Ca}^{2+}$ in endothelial cells (8). This implies that ATP-dependent cellular functions have a differential sensitivity to ATP loss and that anion transport may be one of the more sensitive ones. Thus, changes in ATP levels following acute exposure to oxidants may modulate the rate and perhaps manner of cell killing, although a separate ATP-independent mechanism of cytotoxicity secondary to oxidants exists.

We hypothesized that inhibition of organic anion transport within endothelial cells in association with ATP loss due to oxidant exposure or metabolic inhibition may contribute to the toxicity seen accompanying acute ATP loss in these models of cell injury. We examined two different conditions which produced similar degrees of inhibition of organic anion transport. These conditions (probenecid and metabolic inhibition) produced similar reductions of cellular viability over a 6 -h time course (Fig. 9). This was consistent with the hypothesis that inhibition of organic anion transport in association with ATP loss may be modulating oxidant-mediated cytotoxicity and also be an important contributor to cell injury in ischemia when ATP levels may also be significantly reduced. A defect in cellular lactate export by the organic anion transporter has been postulated to account for skeletal muscle injury following exercise in an otherwise healthy subject (29). Also, eicosanoids have been demonstrated to be transported by similar, probenecid-inhibitable and energy-dependent mechanisms (30). Defective organic anion transport by endothelial cells during ischemia or after oxidant exposure might inhibit the cell's ability to participate in the inflammatory response (e.g., by blocking export of eicosanoid mediators) in addition to causing the accumulation of organic anions like lactate which may exacerbate the injury.

In summary, we have demonstrated that bovine pulmonary artery endothelial cells possess a probenecid-sensitive organic anion transporter. Organic anion transport in the cells is ATP-dependent and $\mathrm{H}_{2} \mathrm{O}_{2}$ inhibits organic anion transport by depleting ATP. We propose that inhibition of organic anion transport may represent a novel mechanism by which oxidants can induce cellular injury and that it may be particularly relevant for understanding ischemic injury.

\section{ACKNOWLEDGMENTS}

The authors thank Ms. Jane Rheault for her excellent assistance with the manuscript and Dr. Ken Guire, Department of Biostatistics, University of Michigan, for his expert assistance with the statistical analysis. This work was supported by a Department of Veterans Affairs Merit Review and also in part by a grant from Lilly Research Laboratories (Indianapolis, IN).

\section{REFERENCES}

1. Henson, P. M., and Johnston, R. B., Jr. (1987) J. Clin. Invest. 79, 669-674.

2. McCord, J. M. (1985) N. Engl. J. Med. 312, 159-163.

3. Schraufstatter, I. U., Hinshaw, D. B., Hyslop, P. A., Spragg, R. G., and Corhrane, C. G. (1986) J. Clin. Invest. 77, 1312-1320.

4. Schraufstatter, I. U., Hyslop, P. A., Hinshaw, D. B., Spragg, R. G., Sklar, L. A., and Cochrane, C. G. (1986) Proc. Natl. Acad. Sci. USA 83, 4908-4912.

5. Schraufstatter, I. U., Hyslop, P. A., Jackson, J. H., and Cochrane, C. G. (1988) J. Clin. Invest. 82, 1040-1050.

6. Cantoni, O., Sestili, P., Cattabeni, F., Bellomo, G., Pou, S., Cohen, M., and Cerutti, P. (1989) Eur. J. Biochem. 182, 209-212.

7. Hyslop, P. A., Hinshaw, D. B., Schraufstatter, I. U., Spragg, R. G., Sklar, L. A., and Cochrane, C. G. (1986) J. Cell Physiol. 129, 356366. 
8. Hinshaw, D. B., Burger, J. M., Armstrong, B. C., and Hyslop, P. A. (1989) J. Surg. Res. 46, 339-349.

9. Schraufstatter, I. U., Hinshaw, D. B., Hyslop, P. A., Spragg, R. G., and Cochrane, C. G. (1985) J. Clin. Invest. 76, 1131-1139.

10. Rubin, R., and Farber, J. L. (1984) Arch. Biochem. Biophys. 228, 450-459.

11. Brodie, A. E., and Reed, D. J. (1987) Biochem. Biophys. Res. Commun. $148,120-125$.

12. Hyslop, P. A., Hinshaw, D. B., Halsey, W. A., Jr., Schraufstatter, I. U., Sauerheber, R. D., Spragg, R. G., Jackson, J. H., and Cochrane, C. G. (1988) J. Biol. Chem. 263, 1665-1675.

13. Baker, M. S., Feigan, J., and Lowther, D. A. (1989) J. Rheumatol. 16, 7-14.

14. Hinshaw, D. B., Sklar, L. A., Bohl, B., Schraufstatter, I. U., Hyslop, P. A., Rossi, M. W., Spragg, R. G., and Cochrane, C. G. (1986) Am. J. Pathol. 123, 454-464.

15. Hinshaw, D. B., Armstrong, B. C., Burger, J. M., Beals, T. F., and Hyslop, P. A. (1988) Am. J. Pathol. 132, 479-488.

16. Hinshaw, D. B., Armstrong, B. C., Beals, T. F., and Hyslop, P. A. (1988) J. Surg. Res. 44, 527-537.

17. Hinshaw, D. B., Burger, J. M., Beals, T. F., Armstrong, B. C., and Hyslop, P. A. (1991) Arch. Biochem. Biophys. 288, 311-316.

18. Mirabelli, F., Salis, A., Marinoni, V., Finardi, G., Bellomo, G., Thor, H., and Orrenius, S. (1988) Arch. Biochem. Biophys. 264, 261-269.
19. Mirabelli, F., Salis, A., Perotti, M., Taddei, F., Bellomo, G., and Orrenius, S. (1988) Biochem. Pharmacol. 37, 3423-3427.

20. Mirahelli, F., Salis, A., Vairetti, M., Rellomo, G., Thor, H., and Orrenius, S. (1989) Arch. Biochem. Biophys. 270, 478-488.

21. Varani, J., Phan, S. H., Gibbs, D. F., Ryan, U. S., and Ward, P. A. (1990) Lab. Invest. 63, 683-689.

22. Hinshaw, D. B., and Burger, J. M. (1990) J. Surg. Res. 49, 222 227.

23. Hinshaw, D. B., Burger, J. M., Delius, R. E., and Hyslop, P. A. (1990) Surgery 108, 298-305.

24. Jacobs, W. R., Sgambati, M., Gomez, G., Vilaro, P., Higdon, M., Bell, P. D., and Mandel, L. J. (1991) Am. d. Physiol. 260, C545C554.

25. Steinberg, T. H., Newman, A. S., Swanson, J. A., and Silverstein, S. C. (1987) J. Cell. Biol. 105, 2695-2702.

26. Omann, G. M., and Harter, J. M. (1991) Cytometry 12, 252-259.

27. DiVirgilio, F., Steinberg, T. H., Swanson, J. A., and Silverstein, S. C. (1988) J. Immunol. 140, 915-920.

28. Spragg, R. G., Hinshaw, D. B., Hyslop, P. A., Schraufstatter, I. U., and Cochrane, C. G. (1985) J. Clin. Invest. 76, 1471-1476.

29. Fishbein, W. N. (1986) Science 234, 1254-1256.

30. Spector, R., and Goetzl, E. J. (1985) Science 228, 325-327. 